\title{
LA FRONTERA ARGENTINO-PARAGUAYA. ETAPAS DE SU DELIMITACIÓN. (1618-1950)
}

\author{
The Argentina-Paraguay Border. \\ Stages of Delimitation. (1618-1950)
}

Ernesto J.A.Maeder

\section{Resumen}

Este trabajo se refiere a las alternativas del proceso político e institucional de delimitación de las jurisdicciones correspondientes a las ciudades de Asunción y Buenos Aires durante la etapa colonial y a la posterior determinación del límite internacional, ya entre los estados soberanos de Paraguay y Argentina, hasta 1876. Finalmente se describe brevemente el desarrollo moderno de los territorios de frontera, a ambos lados del límite fluvial Alto Paraná - Paraguay, en los dos países.

$<$ Frontera Argentina Paraguay $><$ Límite internacional $>$

\begin{abstract}
This paper refers to the political and institutional process of delimitation of the jurisdictions for the cities of Asuncion and Buenos Aires during the colonial times and up to 1876, with the subsequent determination of the international boundary between the sovereign nation-states of Paraguay and Argentina. Finally, there is a brief description of the modern development of the border, on both sides of the fluvial boundary along the Paraguay and Alto Paraná rivers.
\end{abstract}

$<$ Argentina-Paraguay border $><$ International boundary $>$

\section{Introducción}

La relación entre la Argentina y el Paraguay es muy antigua y se remonta a los orígenes de ambas sociedades. En dicha relación no hubo inicialmente una frontera que delimitara las jurisdicciones de las ciudades que, como Asunción y Buenos Aires, se hallaban en los extremos geográficos de aquella vasta gobernación. 
La delimitación entre ambas surgirá cuando las necesidades políticas y eclesiásticas requieran, para una mejor administración, dividir el distrito rioplatense y crear en ese ámbito dos provincias, separadas por límites precisos. A partir de entonces se inició la delimitación de esa frontera; primero fue en la etapa colonial y más tarde, luego de la independencia, en el plano internacional y entre estados soberanos.

En el presente trbajo se refieren las alternativas de ese proceso secular, hasta su delimitación definitiva en 1876. La última parte del mismo está dedicada a describir, sucintamente, el desarrollo moderno de la frontera tanto en el ámbito argentino como en el paraguayo.

Si bien el tema se ha centrado en el proceso político e institucional que preside la demarcación, ello no importa privilegiar una visión restrictiva de la frontera, como línea de separación, sino también su consideración como ámbito de intercambios. De modo particular esa relación varias veces secular estuvo centrada entre el sur del Paraguay Oriental y la provincia de Corrientes, unidas por vínculos históricos, relaciones políticas e intercambios económicos. Es notorio, por otra parte, que esa relación se extendió más tarde a otros tramos de la frontera y se consolidó recientemente con obras de infraestructura y modernas comunicaciones.

Se ha excluido aquí el tratamiento del tramo de la frontera sobre el río Pilcomayo, que por las características de su comportamiento fluvial, merece un tratamiento especial. El propósito de esta reseña es brindar un marco histórico que permita una mejor comprensión de los procesos que conformaron las características de la región fronteriza en conexión con los ríos Paraguay y Alto Paraná.

\section{La época colonial}

Durante la etapa colonial, aunque la demarcación fue inicialmente difusa, se planteó en su momento como un problema jurisdiccional entre provincias hispánicas. Dicha demarcación se confunde o se integra con la demarcación eclesiástica de los respectivos obispados de Asunción (1547) y de Buenos Aires (1620).

El área objeto de la demarcación fue el sector oriental. La región chaqueña, ubicada al occidente, permaneció indivisa, aunque las ciudades fronterizas, como Asunción, Santa $\mathrm{Fe}$, Corrientes o Salta, ejercieron jurisdicción sobre el territorio adyacente.

Una primera etapa en la demarcación fue la que correspondió al período 16171783, mientras que la segunda ocurrió entre 1784 y 1811. Esta última ocurrió en el marco del virreinato del Río de la Plata y la creación de las Intendencias de Buenos Aires y del Paraguay.

\section{Primera demarcación de límites entre Asunción y Buenos Aires}

Luego de consolidada la conquista del Río de la Plata y creada la gobernación homónima (1594), tanto el Paraguay como Buenos Aires constituyeron un distrito integrado al virreinato del Perú y con cabecera en alguna de dichas ciudades. Las distancias 
y los problemas derivados de su extensa jurisdicción determinaron que la corona española dispusiera la división de la provincia en dos distritos. Por Real Cédula del 16.XII.1617 se asignó a la provincia del Guayrá o Paraguay, la jurisdicción sobre las ciudades de Asunción, Villa Rica del Espíritu Santo, Ciudad Real y Santiago de Jerez. A su vez, la provincia del Río de la Plata tuvo su cabecera en Buenos Aires, que finalmente dio nombre a la provincia, que incluía también a Santa Fe, Corrientes y Concepción del Bermejo. Al parecer, no se asignaron límites precisos que demarcaran la jurisdicción de cada una de las provincias. Lo extenso y despoblado del territorio lo hacía, por el momento, innecesario.

Poco después, al crearse el obispado de Buenos Aires, por bula del 30.III.1620, se separó la jurisdicción episcopal de esta sede con la de Asunción. La demarcación coincidió, en general, con la que correspondía a los límites políticos de ambas provincias (Carbia, 1914, Audibert, 1892) ${ }^{1}$.

Dicha delimitación subsistió pacíficamente por largos años. Los gobernantes y obispos realizaron sus visitas a las ciudades y misiones sufragáneas, sin mayores diferencias. Sin embargo, un número creciente de reducciones de indios guaraníes, atendidos por los jesuitas, se fue radicando en un área muy extensa, ubicada precisamente en la región fronteriza de ambas provincias y obispados.

La conmoción que provocó en las Misiones la irrupción de los "bandeirantes" paulistas en la década de 1630, generó el éxodo de los guaraníes y la concentración de las reducciones al oeste del río Uruguay. Allí se radicó una veintena de pueblos entre 1641 y 1685. Cuando, años más tarde se produjo la expansión de las Misiones hacia las tierras de Río Grande los pueblos eran ya treinta. De ellos, trece se hallaban en ambas márgenes del río Paraná y otros diecisiete, a una y otra banda del río Uruguay.

Dicha situación no dejó de crear problemas, pues los diocesanos de Asunción y Buenos Aires no sabían exactamente si la jurisdicción de algunas reducciones era o no de su competencia. A su vez, los conflictos ocurridos en el Paraguay en la primera etapa de la rebelión comunera, dieron lugar a que las reducciones guaraníes de los jesuitas ubicadas en aquel distrito, se asignaran al gobierno de Buenos Aires.

Aunque se trata de dos problemas diferentes, será en la década de 1720 cuando se plantee formalmente la delimitación de ambos distritos, tanto en el plano político como en el eclesiástico. En 1723 el obispo de Buenos Aires, fray Pedro Fajardo, pidió a la corona el deslinde de los pueblos de Misiones de su obispado, "porque cada día hay nuevos pueblos en las doctrinas de los padres jesuitas, para saber cuando toca la canónica institución". Como resultado de ello se emitió una real cédula del 11.II.1724, invitando a los obispos a tratar el problema y remitir el resultado a la Audiencia de Charcas (Pastells, 1930).

\footnotetext{
${ }^{1}$ Según Carbia, en 1648 el obispo de Buenos Aires, Mancha y Velazco, hallándose en la reducción jesuítica de Santa Ana, señaló que el río Paraná sería el límite entre ambas diócesis, no sólo por ser caudaloso y navegable, sino porque "al tiempo de la división y erección de la Iglesia, se reconoció esto mismo". Rómulo D. Carbia, Historia eclesiástica del Río de la Plata, Bs. As., 1914, tomo I, 113, nota 2. A su vez, Alejandro Audibert cree que la tradición indica que el límite se hallaba en el río Bermejo y el Paraná, hasta las Misiones. Los límites de la antigua provincia del Paraguay, Bs. As., 1892, 135.
} 
La cuestión se dilató como consecuencia del conflicto comunero. Finalmente, ambos obispos decidieron que la delimitación se sometiera a un laudo arbitral, que determinara cuáles pueblos de Misiones se hallaban en una u otra jurisdicción. ${ }^{2}$ (Audibert, 1892:137). El texto de dicho laudo está fechado en Candelaria el 8.VI.1727 y fue refrendado por los padres José Insaurralde, Superior de Misiones y Anselmo de la Mata, cura de San Ignacio Guazú. En el mismo se expresa que los "términos del obispado del Paraguay, son e incluyen las vertientes todas del río Paraná y los del obispado de Buenos Aires, las del río Uruguay, que son divisorias de ambos obispados". Es interesante advertir que en la oportunidad no se tomó como límite el curso del río, sino el área bañada por las respectivas vertientes que desaguaban en él.

A continuación examinaron la situación de algunos pueblos en particular, tales como Candelaria, SS. Cosme y Damián, Santa Ana, Trinidad y San José, que se hallaban en litigio, determinado que "Los pueblos no deben ser del territorio de origen, sino del que está fundado" y que en caso de dividirse algunos pueblos "y formarse colonias, sigan éstos no el territorio de origen, sino el de donde se fundaren, según los límites y territorios expresados de ambos obispados (Trelles, 1867, Audibert, 1862).

Sin perjuicio de este laudo arbitral, una real cédula del 24.IX.1732 dirigida a la Audiencia de Charcas reclamaba que se diera cuenta a la corona de lo obrado en materia de límites entre ambos obispados y se remitieran los documentos correspondientes, incluyendo el informe de los gobernadores de cada distrito (Pastells, 1930).

A su vez, en el aspecto político y como consecuencia del conflicto suscitado por los comuneros en el Paraguay, el P. José Rerrán, procurador de la provincia Jesuítica, solicitó al rey el 14.X.1726 que atento a los problemas y temores suscitados en las Misiones, "los treinta pueblos a cargo de la Compañía de Jesús queden a cargo del gobernador de Buenos Aires, e inhibidos del Paraguay sus ministros". Como resultado de ello y de otras consideraciones políticas, una real cédula del 6.XI.1726 dispuso la extensión de la jurisdicción bonaerense sobre todas las reducciones jesuíticas de guaraníes. Sin perjuicio de ello, el gobernador Bruno Mauricio de Zavala, admitió que los "cuatro pueblos más cercanos al Paraguay queden en dependencia política de aquel gobierno, hasta que $\mathrm{Su}$ Majestad resolviese". El 14.VII.1730, el Consejo de Indias aconsejaba al rey se mantuviese esa medida propuesta por Zavala. ${ }^{3}$ (Pastells, 1930, VII:65-66).

\section{La frontera entre 1768 y 1810}

En las últimas décadas de la etapa colonial, la delimitación fronteriza experimentó algunos cambios en su trazado.

El primero de ellos tuvo por origen la creación de la Provincia de Misiones, en el área ocupada hasta entonces por las reducciones de guaraníes. La expulsión de los jesuitas en 1767 y la secularización de ese territorio en 1768 significaron, desde el ámbito político

\footnotetext{
${ }^{2}$ Se acordó dicho laudo el 30 de junio y 31 de julio de 1726 a los jesuitas de Misiones.

${ }^{3}$ Una Real Cédula del 24.IX.1732 reclama a la Audiencia de Charcas que de cuenta de los límites entre ambos episcopados, y que los gobernadores informen sobre ello.
} 
la creación de un nuevo distrito, con autoridades propias subordinadas al gobernador de Buenos Aires. En lo territorial, dicho distrito incluyó los treinta pueblos de las misiones, así como las tierras que ocupaban sus estancias en ambas márgenes de los ríos Paraná y Uruguay. Ello conformaba la decisión de 1726, al dejar ahora en forma que parecía definitiva, todo el territorio de Misiones bajo la dependencia de Buenos Aires. En razón de ello la frontera del Paraguay con Misiones, y desde luego, con Buenos Aires, se mantenía en el río Tebicuary.

Para su mejor administración, la provincia de Misiones fue fraccionada en cinco departamentos desde 1773. Dos de ellos, con cabecera en Santiago y de Candelaria, y un total de trece pueblos, se hallaban ubicados en ambas márgenes del río Paraná. Los otros tres departamentos de Concepción, Yapeyú y San Miguel, con un total de diecisiete pueblos, se ubicaban en las vertientes del río Uruguay.

Después de haberse establecido el virreinato del Río de la Plata en 1776, se aplicó el régimen de intendencias a partir de 1783, lo cual significó modificaciones en la organización política y territorial de las antiguas provincias. De conformidad con esa norma, los límites de cada distrito debían corresponder con las fronteras del respectivo obispado. En el caso del Paraguay, los límites del obispado de Asunción incluían a dos de los departamentos de la provincia de Misiones, Santiago y Candelaria. Así lo entendió el gobernador intendente del Paraguay, Pedro de Melo, quien el 13.IV.1784 ofició al virrey Marqués de Loreto, señalándole que "Los pueblos que por el nuevo establecimiento ha recibido en su jurisdicción en lo temporal son trece: cinco corresponden al departamento del río Tebicuary, que son Santiago, San Ignacio Guazú, Nuestra señora de Fe, Santa Rosa y Santos Cosme y Damián, y los de la vertiente del río Paraná, a una y otra banda, son, Itapúa, Trinidad, Jesús, Candelaria, San Ignacio Miní, Santa Ana, Loreto y Hábeas.”

Luego de recordar al virrey la adjudicación de dichos pueblos a Buenos Aires entre 1726 y 1768, así como la asignación de los mismos al gobierno de Misiones, concluye señalando que en virtud de la Ordenanza de intendentes, "este gobierno e intendencia comprende bajo su jurisdicción todo el territorio que abraza el obispado, por cuyo motivo se han agregado dichos pueblos a ella". Así lo comprendió el virrey, que por disposición de1 14.VII.1784 aprobó lo actuado por el gobernador Melo (Audibert, 1892: 320-323).

De ese modo, la gobernación de Misiones quedó políticamente en dependencia de dos gobiernos y de dos obispos. A su vez, la frontera entre ambas intendencias quedó establecida, al menos en el sector de Misiones, en el mismo límite que se le había acordado en el laudo de 1726.

Sin embargo, esta situación volverá a modificarse dos décadas después. La ocupación portuguesa del departamento de San Miguel, en 1801 y las dificultades que experimentaban para una adecuada administración de Misiones, dieron lugar a que el 17.V.1803 la corona creara el Gobierno militar y político de Misiones, "con total independencia de los gobiernos del Paraguay y de Buenos Aires, bajo los cuales se hallan divididos en el día" (Audibert, 1892. 323-324). Ello significó volver a unificar la provincia, y consecuentemente, el límite entre Paraguay y Buenos Aires, ahora constituido por todo el territorio provincial de Misiones. 


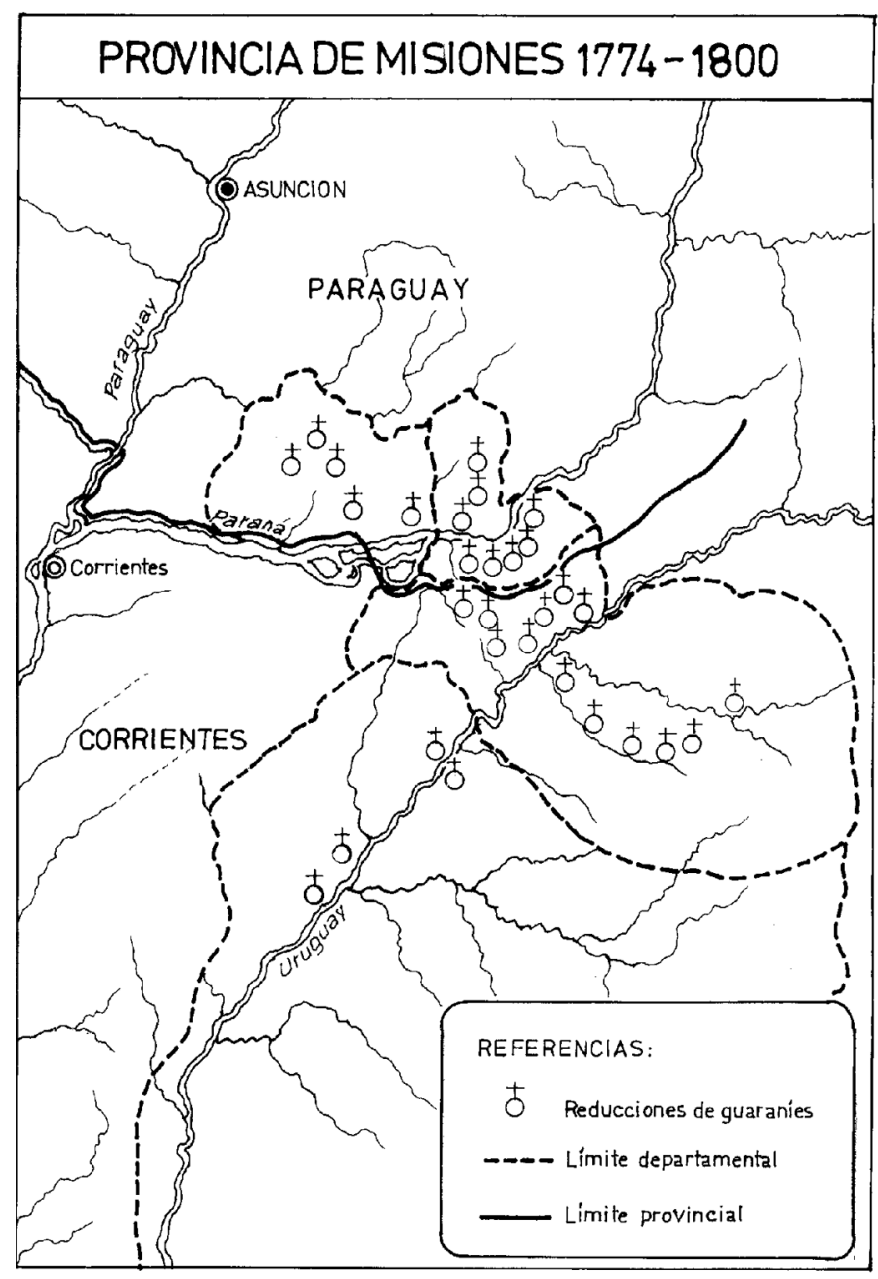

Pero la medida no fue duradera. Poco después una Real orden del 12.IX.1805 confirió al coronel Bernardo Ve1 azco, gobernador de Misiones, la intendencia del Paraguay "con agregación del de Misiones". Velazco se hizo cargo de ambas gobernaciones en Asunción el 5.V.1806. Pero esta unión de ambos gobiernos en una sola persona también fue efímera. El 2.V.1808, el virrey Santiago de Liniers nombró en Misiones un Comandante General de Armas en ausencia de Velazco, retenido en Buenos Aires luego de su participación en las invasiones inglesas. A su regreso a Asunción, reclamó por la medida inconsulta del virrey; el comandante Agustín de la Rosa renunció a su cargo y el nuevo virrey Baltasar Hidalgo de Cisneros, sugirió al gobernador Velazco que, dadas las dimensiones de los distritos a su cargo, parecía necesario crear una jefatura que actuara en Misiones en calidad de subordinada a su gobierno. Velazco se avino a ello y el virrey confirió la comandancia de armas de Misiones a Tomás de Rocamora, quien se hizo cargo de ella a principios de 1810 (Audibert 1892: 325-345). 
De modo que Misiones volvió a gozar de una nueva y relativa autonomía, aunque en dependencia de las autoridades de Asunción. La revolución de Mayo y el desplazamiento de la expedición de Manuel Belgrano al Paraguay, habrían de modificar muy en breve ese estado de cosas. Con ello se abrirá una nueva etapa en la delimitación de la frontera entre ambas naciones.

\section{La demarcación en el Chaco}

La región chaqueña o Gran Chaco, se halla ubicada al oeste de los ríos Paraguay y Paraná. Constituye una vasta planicie que se extiende desde la actual ciudad de Santa Cruz de la Sierra, en Bolivia y llega en su límite meridional hasta la población de Calchaquí, en la provincia de Santa Fe. Sus límites hacia el oeste incluyen importantes sectores de Santiago de Estero y de Salta.

El Chaco puede ser dividido en tres sectores diferentes según su ubicación geográfica; el ubicado al norte del río Pilcomayo responde a la denominación de Chaco Boreal, el situado entre ese río y el Bermejo, es el Chaco Central y el que se halla al sur de este último río se conoce como Chaco Austral.

Dicha región se mantuvo durante toda esta etapa ajena a la conquista española y bajo el dominio de los pueblos indígenas que la habitaban desde tiempo inmemorial. En la etapa colonial hubo intentos de poblar la región y de instalar reducciones para los grupos aborígenes. Diversas expediciones recorrieron su territorio y la cartografía coetánea refleja los conocimientos que a lo largo de esa etapa se fueron adquiriendo por los exploradores, misioneros y soldados.

Las dos fundaciones más importantes, Concepción del Bermejo (1585-1631) y Esteco (1567-1692) no llegaron a sostenerse y fueron abandonadas por sus pobladores. En uno y otro caso se establecieron en el interior del Chaco Austral y fueron fundadas por colonizadores provenientes de Asunción en el primer caso y del Tucumán en el segundo.

Otra etapa la cumplieron las reducciones jesuíticas que se fundaron en el Chaco en el siglo XVIII. Cada una de ellas fue promovida desde las ciudades vecinas a dicha frontera: San Carlos y Rosario del Timbó desde Asunción; San Fernando desde Corrientes, San Javier y San Pedro, desde Santa Fe. Otro tanto ocurrió con las reducciones que fueron ubicadas en la frontera Tucumano Salteña sobre el Chaco Occidental. Casi todas languidecieron después de la expulsión de los jesuitas en 1767.

En las últimas décadas se fundaron otras reducciones en el Chaco Austral, algunas, como Santiago y La Cangayé y San Bernardo El Vértiz (1780) provenientes desde el Tucumán y otras como Remolinos (1778), Naranjay (1782) y Melodía (1787) orientadas desde Asunción. Estas últimas en el Chaco Central y Boreal.

De todos modos, no parece que se haya planteado formalmente una delimitación entre las provincias de Buenos Aires y Paraguay sobre aquella región chaqueña. La impresión que prevalece y que los hechos confirman, es que cada ciudad limítrofe ejercía alguna forma de jurisdicción sobre la parte del Chaco que se hallaba frente a ella. Lo 
prueba el origen de las reducciones que allí se establecieron. Uno de los pocos testimonios de la división jurisdiccional en el Chaco puede hallarse en la Real Cédula de 1617 que adjudicó a Buenos Aires la ciudad de Concepción del Bermejo, pero desaparecida ésta, no se reitera en otra documentación.

El testimonio de algunos autores como Diego de Alvear, sugiere que el límite convencional se hallaba en el Chaco Central. En su obra, Relación histórica y geográfica de la Provincia de Misiones (1792) este oficial, al referirse a la evolución de la provincia del Paraguay señala:

"Está hoy reducida la jurisdicción del Paraguay a los Llanos de Manso [Chaco Central, hoy Formosa] entre los ríos Bermejo y Pilcomayo que le entran de occidente al Gran Chaco, entre éste y el Paraguay y a los terrenos que encierra éste con el Paraná por el levante, terminando sus confines, por la parte del aquilón \{Norte\} la serranía de Mbaracayú y por el austro \{sur\} los esteros o bañados de Ñeembucú, poco antes de la citada confluencia de los dos grandes ríos, que es lo que con propiedad se llama Provincia del Paraguay". (Alvear, 1836 cap.1, parágrafo 3).

En definitiva y en lo que a esta región se refiere, todo parece indicar que el Chaco Central era la división entre las provincias e intendencias de Buenos Aires y del Paraguay.

\section{Un litigio en la frontera con Corrientes}

Otro ámbito conflictivo de la delimitación fronteriza con el Paraguay correspondió a la ocupación de una parte de la margen norte del río Paraná, entre Itatí y Paso del Rey, [hoy Paso de la Patria] por parte de la ciudad de Corrientes a fines del siglo XVIII.

Hacia el norte de ese tramo del Paraná se extiende la región del Ñeembucú. La misma, es una planicie con lomadas dispersas, de escaso drenaje, con predominio hacia el oeste de esteros de grandes dimensiones, limitada por los ríos Paraguay al oeste, Paraná al sur, Tebicuary al norte, y el Yabebirí hacia el este.

Esta región se hallaba despoblada desde sus orígenes y constituía una vía de fácil entrada para las correrías y pillajes de los indios del Chaco, que se deslizaban allí hacia las estancias de los pueblos guaraníes de las Misiones jesuíticas de San Ignacio Guazú, Santa Rosa, Nuestra Señora de Fe y Santiago, que se hallaban ubicadas hacia el este del Yabebirí y al sur del Tebicuary.

El ejercicio de jurisdicción sobre esta región sólo se puso de manifiesto en época tardía. Alguna forma de tráfico se realizaba en Itatí y la costa del Paraguay, aunque el cruce de ganado más frecuente se efectuaba por los pasos de Itapúa [hoy Encarnación] y de Candelaria, ambos en el área de las Misiones.

En los años 1767-1769, el cabildo de Corrientes consideró la posibilidad de reabrir el paso de Itatí, así como la conveniencia de fundar un fuerte o presidio en Curupaití, y 
asentarse también en las Lomas de Pedro González. Como resultado de ello se alentó desde Corrientes el envío de una expedición que concretó esa acción en abril de 1779 . En Curupaití se erigió una empalizada y alojamiento para los pobladores del lugar, que llevaron al lugar arreos de ganado.

En coincidencia con la ocupación de ese sitio, los paraguayos, por intermedio de su gobernador dirigieron una formal protesta sobre la iniciativa correntina, al tiempo que tomaban medidas para lograr el mismo propósito en la costa del río Paraguay, en vecindad con Curupaití. La reacción paraguaya respondía al convencimiento de hallarse en territorio propio y a la necesidad de continuar su acción pobladora en el suroeste de la provincia. Y si bien Ñeembucú se mantenía despoblada hasta ese momento, se habían fundado en la periferia de la región los pueblos de Bobi en 1773 y Quiquió en 1777. Esa voluntad de proseguir con la ocupación y el poblamiento de la región fue expresada por el gobernador Pedro Melo en carta al virrey del 13.VIII.1778, en la que le solicitaba "se digne declarar por término de esta gobernación y el de Buenos Aires y sus tenencias [en alusión a Corrientes] el mencionado río Paraná, límite que siempre ha sido de esta Provincia...” (Maeder, 1981: 84).

La presencia correntina en territorio que Melo consideraba paraguayo, movió a su gobierno a ocupar también otra fracción de Curupaití, al tiempo que solicitaba a los correntinos su retiro del lugar, hasta que el virrey resolviera el problema.

Al mismo tiempo, decidió reforzar su dominio en la región estableciendo una guardia en Herradura y el 5.X.1779 fundando en la desembocadura del Tebicuary el pueblo de Nuestra Señora del Pilar de Ñeembucú.

Como consecuencia de la disputa por ese lugar, el virrey debió laudar entre ambos intereses, dividiendo ese sitio en partes iguales, separadas por el arroyo Hondo. Unos y otros otorgaron mercedes de tierras en la zona. Corrientes habilitó el Paso del Rey en 1782 y Paraguay estableció un fuerte en Tacuaras, en el mismo año. De hecho, Curupaití parecía más bien un enclave correntino en el sur del Paraguay, pero sin posibilidades de ensanchar su dominio, limitado por la política pobladora del Paraguay, como por dificultades que ofrecía ese espacio, apto sólo para la cría de ganado en condiciones limitadas.

La indefinición del conflicto, los incidentes entre ambos ocupantes, la reiteración de los reclamos paraguayos, la elevación de Pilar de Ñeembucú al rango de villa en 1787, la fundación de Laureles en 1790, parecía cerrar toda posibilidad de que el asiento correntino llegase a consolidarse, con el consiguiente desaliento de sus ocupantes.

Al pleito civil se sumó un conflicto de jurisdicción eclesiástica entre el cura de Corrientes y sus feligreses de Curupaití y el cura de Pilar de Ñeembucú, hecho que reprodujo en ese fuero la misma cuestión que se tramitaba en el plano político.

Finalmente la cuestión se resolvió por las vías de hecho. Como resultado de la expedición de Manuel Belgrano al Paraguay, las tropas de esta provincia ocuparon Curupaití el 27.IX.1810 de modo definitivo. Con ello la posesión correntina en aquella fracción del Paraguay quedó definitivamente extinguida. 


\section{Los remotos orígenes del contrabando fronterizo}

El intercambio entre Corrientes y el Paraguay era de antigua data, ya que las existencias de ganado no alcanzaban para las necesidades de los paraguayos. Esa situación recién comenzó a modificarse cuando el Paraguay comenzó una etapa de expansión territorial y pudo con ello ampliar sus áreas de cría y pastoreo.

La cantidad de animales remitida desde Corrientes a esa provincia se incrementó en la época virreinal: entre 1780 y 1797, se remitieron al Paraguay 149.000 vacunos, 59.000 equinos y 4.500 mulas. Dichos arreos se cruzaban por el paso de Itatí, y desde 1782, por el Paso del Rey. En ambos lugares se cobraba como peaje el 10\% del arreo si el cruce era en balsas y el 5\% si era a nado. El destino de esos animales se dirigía, casi siempre a Villa Rica, y desde la década de 1780, quedaba en las nuevas estancias ubicadas en el Ñeembucú.

Otros rubros importantes fueron la yerba y el tabaco. La primera provenía del Paraguay o de Misiones, ya que Corrientes carecía de ese producto. En cuanto al tabaco, el abastecimiento era de menor importancia ya que también había algunos cultivos en Corrientes.

Cuando en 1779 se creó por decisión real el Estanco del Tabaco, a fin de incrementar las rentas fiscales, la situación se modificó en el área fronteriza de Corrientes y Paraguay. El estanco suponía el monopolio de ese bien por el Estado, que se constituyó en el único adquirente de la producción, elaboración y venta del tabaco en rama y en polvo. En tal sentido, Francisco de Paula Sanz, nombrado Director de la Real Renta de Tabaco y Naipes, luego de su visita al Paraguay, estableció que aquella provincia era centro de producción de tabaco para todo el virreinato. Ello excluía la posibilidad de su cultivo en otras partes. (Maeder, 1981).

Como resultado de ello, la Real Renta de Tabaco fijaba el precio, compraba a los productores privados la producción, la acopiaba en sus depósitos y la distribuía a través de los estancos subordinados en las distintas ciudades y pueblos del virreinato. Ello dio como resultado el nacimiento del contrabando de tabaco en la frontera, al introducirse en Corrientes partidas de tabaco con destino a las provincias vecinas, burlando al estanco y a precios más baratos. La ubicación de Corrientes la convertía en la zona de paso obligado, tanto desde el Paraguay, como desde las Misiones, que gozaban del privilegio de autoabastecerse. A ello debe añadirse el contrabando incipiente a través de la frontera del Brasil, que desde 1801 fue tomando mayor volumen.

Para hacer frente a este problema se creó en Corrientes el Resguardo, una suerte de cuerpo de vigilancia encargado de controlar el cumplimiento del monopolio de la adquisición y venta de tabaco a través del Estanco. Este cuerpo contó inicialmente con un visitador, un teniente y guardas, que en 1787 eran ya siete personas. Este Resguardo, un remoto antecedente del moderno personal de Aduanas, estaba autorizado a pedir auxilio a las autoridades locales. Su deber le imponía la vigilancia del tráfico ilegal y la inspección de las cargas fluviales y terrestres. 
El efecto del contrabando se dejó sentir desde el inicio mismo de la creación del Estanco. Los caminos y los medios utilizados constituyeron un largo capítulo en el cual el ingenio dio alas a un comercio clandestino, que hasta ese momento no había tenido mayor significado en la economía rioplatense. Por otra parte provocó una creciente preocupación en las autoridades del Estanco, que debieron atender denuncias y realizar decomisos cada vez más frecuentes.

La autorización para que los marineros paraguayos pudieran llevar hasta tres mazos de tabaco para su consumo personal, abrió una puerta inicial a los abusos, ya que se comprobó que estos revendían fraccionada su provisión en los puertos del itinerario.

Los barcos mayores llevaban tabaco disimulado entre las cargas y petates; las canoas evitaban la costa correntina, recostándose sobre la banda del Chaco, para vender tabaco a los indios de San Javier y de San Jerónimo, que a su vez estos revendían en Santa Fe o en el Tucumán. Siembras clandestinas se hicieron en las tierras en litigio de Curupaití o en el Ñeembucú, donde al amparo de la precaria frontera, los paraguayos obstaculizaban las inspecciones de los guardas del Resguardo correntino. Cuando el control se tornaba más celoso, el contrabando se hacía en pequeñas balsas que cruzaban en Itá Ibaté o en Yahapé, ingresando al mercado ilegal y haciendo más difícil la colocación del tabaco vendido por el Estanco, en razón de la diferencia de precios.

El crecimiento de este tráfico ilegal hizo necesaria la colocación de guardias permanentes en Paso del Rey, Curupaití, ltatí y desde 1787, también en la tranquera de Loreto, camino a las Misiones. Pero estos hombres, aislados y faltos de otros medios, poco podían hacer para remediar el problema. Desde 1788 se los proveyó de botes y en 1791 hubo de agregarse al Resguardo la dotación para tripular una falúa corsaria, nombrada Santa Bárbara.

En esa misma fecha el virrey dispuso que los barcos que navegaban desde Asunción fueran registrados en Humaitá y en Curupaití. En 1792 se suprimió el privilegio dado a los tripulantes de llevar tabaco para su consumo. En 1793 se agregó otra falúa, la San Antonio, para controlar el tráfico fluvial a la altura de Santa Fe.

El aumento de los controles se dejó sentir, ya que aumentaron los decomisos y mejoraron las ventas del Estanco. Pero también provocaron ocasionales roces con los paraguayos, menos celosos que los correntinos en el control.

A pesar de la victoria parcial del Estanco, el control declinó cuando las falúas cumplieron su vida útil y los contrabandistas aprovecharon sus ausencias para infiltrar nuevamente su mercadería. Desde 1805 este problema se agravó y en 1808 , el virrey Liniers, informado de ello, autorizó la represión del contrabando con medidas excepcionales. Sin embargo, el éxito fue limitado y los rozamientos con funcionarios de Corrientes, sospechados de tolerancia o complicidad, obligaron a suspender dichas medidas. Entre 1809 y 1810, el contrabando parecía haber vencido al Estanco.

De todos modos, el Estanco no había sido visto con buenos ojos por Corrientes. El cabildo planteó, más de una vez, la necesidad de autorizar el cultivo de tabaco en 
Corrientes, favoreciendo así a la producción local y disminuyendo las posibilidades de contrabando. Pero sus razones no fueron atendidas.

La supresión del Estanco en 1812 y el aislamiento del Paraguay favorecieron el arraigo de ese cultivo en Corrientes y sirvió, al menos por un tiempo, para que se olvidara el contrabando de tabaco en esa frontera.

\section{La demarcación en la época nacional}

En la época colonial, la demarcación fronteriza en el Chaco no había sido establecida de modo formal. Un consentimiento tácito entre las intendencias de Buenos Aires y Salta del Tucumán, así como la escasa presencia colonial en un territorio ocupado exclusivamente por las naciones indígenas, permitió aquel statu quo fronterizo en el Chaco Central, o en el cauce del río Bermejo.

En la etapa posterior a la emancipación nacional, esa situación comenzó a modificarse en dos ámbitos diferentes del Chaco Central: el sector oriental en el que se interesaba el gobierno de Asunción y el occidental, promovido desde Salta. En ambos casos supuso acciones defensivas, instalación de poblaciones y proyectos de navegación y colonización que implicaban jurisdicción sobre esa parte del Chaco Central. En el Chaco Austral, al sur del río Bermejo y el Chaco Boreal, al norte del Pilcomayo, se hallaban a una y otra parte de la demarcación fronteriza en cuestión.

\section{La demarcación en el Chaco Central Oriental}

En el último tercio de la época colonial y después del abandono de la reducción jesuítica de abipones, en el Timbó, el gobierno de Paraguay fundó y mantuvo por algún tiempo otras reducciones en la costa chaqueña. Ellas fueron San Francisco Solano, de indios mocobíes y Naranjay de indios tobas. A ellos se sumaron las de Melodía de indios lenguas y otros, que bien o mal subsistieron algunos años. Todas ellas fueron ubicadas en el territorio del Chaco y al norte del río Pilcomayo. Ellas se correspondían además, con la línea de fuertes ubicados en el margen izquierda del río Paraguay, al sur y al norte de Asunción, cuya función era vigilar y eventualmente impedir incursiones de los indios chaqueños sobre el territorio paraguayo.

Después de la revolución de 1811 y ya bajo el gobierno del dictador Gaspar Rodríguez de Francia, dicha línea de fuertes se modificó, incluyendo cuatro guardias ubicadas en la costa chaqueña y más precisamente en el Chaco Central, actual provincia de Formosa.

Dichas guardias de norte a sur se denominaron Santa Elena, Monteclaro, Orange y Formoso. Su origen se remonta a 1817 y se conocen diversos pasos administrativos que llevan la firma del dictador. En 1822 decía que ${ }^{4}$ "el principal objeto de establecerse aquel presidio [se refiere a Monteclaro] ha sido el resguardar de las invasiones de indios

\footnotetext{
${ }^{4}$ La presencia paraguaya en dicha región, entre 1845 y 1865 , se halla extensamente documentada en el Archivo Nacional de Asunción, en las secciones Histórica y Nueva Encuadernación.
} 
la estancia del estado situada entre los ríos Surubí y Paroi [ubicada en la orilla opuesta al fuerte]".

La ubicación de los mismos ha sido posible gracias a la cartografía y toponimia de la época. El caso más notorio es el de Formoso, cuya denominación deformada ha dado lugar al topónimo Formosa, nombre de la actual ciudad y capital de la provincia homónima.

$\mathrm{Al}$ parecer, el mantenimiento de dichos fuertes se mantuvo hasta 1848. En ese año, un decreto del presidente Carlos Antonio López dispuso que el comandante de Vila Franca cruzara al fuerte Formoso y "pegara fuego a los ranchos, potreros y maderas y hará trasladar a la margen izquierda del río [Paraguay] al expresado fuerte, sea en el piquete actual o en el punto que le parezca más conveniente, todo lo que sea útil y de fácil transporte... y allí mandará procurar brevemente una guardia provisoria..."

Los fundamentos de dicha orden aluden al costo de mantenimiento del fuerte, su escasa utilidad, ruina de sus edificios y la presunción de que el gobierno de la Confederación Argentina podría invadir el Paraguay, intentando ${ }^{5}$ un golpe de mano sobre la capital, corriéndose alguna fuerza por el Chaco.( Maeder, 1979: 439-452).

En la misma fecha se produjo el desmantelamiento del fuerte Orange. Los de Santa Elena y Monteclaro parecen haber sido abandonados antes de 1848.

Mientras esto ocurría en el tramo del Chaco Central Oriental, al norte del Pilcomayo y sobre la ribera del río Paraguay, se habían poblado algunos lugares como Rinconada, Guardia Pilcomayo y Piquete Pilcomayo, de los cuales poco se conoce.

\section{La frontera del río Bermejo cuestionada}

En la época colonial, el Bermejo y los territorios aledaños habían sido objeto de exploraciones, navegación y proyectos de colonización que no llegaron a concretarse.

En épocas posteriores, ese interés se renovó, tanto desde la provincia de Salta como desde el gobierno nacional. En 1824, un vecino de Jujuy, Pablo Soria, promovió la navegación de ese río y obtuvo del gobierno de Salta la concesión para ese tráfico por un plazo de quince años. Una sociedad por acciones creada al efecto, financió la navegación de ese río, que Soria llevó a cabo en 1826. Luego de recorrer el río Bermejo en toda su extensión, se encontró con la desagradable sorpresa que una guardia paraguaya en Tallí, cerca de la desembocadura en el río Paraguay, lo hiciera prisionero. El gobierno de ese país lo confinó hasta 1813. La empresa fracasó, pero puso de manifiesto la voluntad del Paraguay por controlar ese cauce fluvial y el territorio limítrofe.

A su vez y desde el gobierno argentino, el presidente Rivadavia promovió y obtuvo del Congreso Nacional en 1826, un proyecto destinado a promover la navegación

\footnotetext{
${ }^{5}$ En la organización política de la República del Paraguay, los departamentos son unidades administrativas, a cuyo frente se hallan autoridades delegadas del Poder Ejecutivo, tal como lo dispone el artículo 14 de la Constitución de 1967. Ello los asemeja a los departamentos en que se dividían administrativamente las provincias y territorios argentinos.
} 
del Bermejo y la colonización de sus tierras en ambas márgenes del río. El proyecto, como es sabido, no llegó a ejecutarse.

Pocos años después, José Arenales volvió sobre la misma idea, plasmada en su libro Noticias históricas y descriptivas sobre el Gran país del Chaco y río Bermejo, con observaciones relativas a un plan de navegación y colonización que se propone, editado en Buenos Aires en 1833. Por su parte, no sólo Salta, sino también Bolivia comenzó a interesarse en la exploración de vías fluviales como el Pilcomayo que permitieran la comunicación con la cuenca del Río de la Plata.

Si bien estos proyectos no llegaron a cuajar, se hizo patente la necesidad de definir fronteras, no ya entre las antiguas intendencias virreinales, sino entre tres estados nacionales que limitaban en el Chaco y que se interesaban en los ríos Bermejo y Pilcomayo como posibles vías de comunicación. De hecho, la cuestión fronteriza se aproximaba a una definición que tuvo lugar en la segunda mitad del siglo XIX. Tras la derrota de Rosas en Caseros, la Confederación Argentina reconoció la independencia del Paraguay y llegó a un acuerdo general de entendimiento. En ese acuerdo, rubricado por los representantes Varela y Derqui y firmado en Asunción el 17.VII.1852, se reconoció al Paraguay la soberanía sobre los territorios a ambas costas del río Paraguay y la navegación compartida del río Bermejo, constituido en límite sobre el Chaco. Pero al ser considerado este acuerdo por el Congreso de la Confederación, dichos artículos sobre límites fueron rechazados. De ese modo la demarcación en esa región quedó nuevamente en suspenso.

\section{La demarcación en el ámbito de Corrientes y Misiones}

En esta etapa, la demarcación de los límites entre el Paraguay y las provincias de Corrientes y Misiones atravesó por una situación sumamente compleja.

Por una parte, la delimitación de dichos distritos dejó de ser una cuestión entre provincias o intendencias de un mismo virreinato, cuya resolución se debía resolver dentro de la jurisdicción y. las normas de la monarquía española. A partir de la Revolución de Mayo y sobre todo, desde la independencia de hecho que exhibió el Paraguay desde 1811, el litigio se planteó entre estados autónomos y no como provincias de una misma nación. A su vez Corrientes, constituida en provincia separada de la intendencia de Buenos Aires desde 1814, también procuró manejar sus relaciones limítrofes con sus vecinos con cierta independencia. Ello se vio impulsado en algunas ocasiones, por los conflictos armados con que la provincia se enfrentó al liderazgo de Rosas, encargado de las relaciones exteriores de la Confederación Argentina y que la llevaron a buscar alianzas y concesiones en materia de límites con su vecina Paraguay. En otras ocasiones el clima entre ambas fue de hostilidad, particularmente en el área cercana a las Misiones. Esta situación comenzó a encauzarse diplomáticamente luego del reconocimiento argentino de la independencia del Paraguay en 1852.

La situación limítrofe entre Misiones y Paraguay volvió a adquirir importancia en 1811. Luego de la derrota de la expedición de Belgrano y la posterior asunción de las nuevas autoridades paraguayas, se acordó el 12.X.1811 una alianza, entre la Junta de 
Buenos Aires y la de Asunción, así como medidas sobre comercio y límites. El artículo $4^{\circ}$ establecía que "los límites de esta provincia del Paraguay quedarán en la forma en que actualmente se hallan, encargándose su gobierno de custodiar el departamento Candelaria". Cabe recordar que el departamento aludido incluía ocho pueblos: tres de ellos en la margen derecha del río Paraná y cinco en la margen izquierda. El gobierno de Buenos Aires no aprobó ese artículo, encomendando su revisión. A su vez, el gobierno de Asunción recordó su antigua jurisdicción real y episcopal sobre ese distrito, añadiendo que ${ }^{6 "}$ "no obstante se tendrá presente este punto para tratar en el primer congreso que se celebre de sus vecinos y moradores, de cuyo común sufragio dependerá la resolución del caso.” (Trelles, 1867:181 y Sánchez Quell,1964:12-13 ).

A partir de entonces la cuestión quedó en ese estado. La independencia y aislamiento con que procedió el gobierno del Paraguay durante la larga dictadura de Gaspar Rodríguez de Francia (1815-1840), no dio lugar a nuevos contactos sobre este aspecto. A su vez, la caducidad de las autoridades en Argentina desde 1820, dejó en manos de la provincia de Corrientes la vigilancia sobre las cuestiones fronterizas.

A ello ha de añadirse la grave situación en que se hallaban los restantes departamentos de Misiones en jurisdicción argentina. Tanto el de Yapeyú como el de Concepción resultaron devastados por las tropas portuguesas que invadieron la región con el propósito de derrotar a los aliados de Artigas. A ello se sumó la despoblación de los mismos. También los cinco pueblos del departamento Candelaria, ocupados por el Paraguay, sufrieron los efectos de la guerra y concluyeron destruidos y despoblados. Parte de sus habitantes emigraron al oeste de la laguna Iberá y dieron lugar a la formación de los nuevos pueblos de Loreto y San Miguel (Poenitz y Poenitz, 1993 y Maeder, 1992).

De modo que el nordeste de Corrientes y Misiones quedaron abandonados y bajo la vigilancia del Paraguay. De hecho, la frontera de Corrientes quedará establecida en la Tranquera de Loreto (hoy departamento de Ituzaingó) y desde allí al este se extenderá un territorio virtualmente desierto bajo el control paraguayo.

En años posteriores hubo tensiones entre ambos estados, al punto que se temió un conflicto armado. En 1832 el Paraguay ocupó la isla de Apipé y estableció un campamento militar en la Rinconada de San José, conocida también como Trinchera de los paraguayos (hoy Posadas). En torno a dicho campamento se edificó posteriormente una muralla de piedras que se concluyó en 1838. La consolidación del dominio paraguayo en ese espacio tenía además el propósito de proteger el comercio terrestre que se estableció entre Itapúa (hoy Encarnación) y San Borja, en Brasil, y que atravesaba el entonces despoblado sur de Misiones y la costa correntina del río Uruguay. (Williams, 1973, Lorenzo y Snihur, 1991).

\footnotetext{
${ }^{6}$ Para la República Argentina se han examinado los censos nacionales de 1895, 1914, 1947, 1960 y 1970. Para la República del Paraguay, los censos nacionales de 1886, 1899, 1950 y las estimaciones de 1914 y 1936. Estas últimas en Raúl A. Mendoza, Desarrollo y evolución de la población paraguaya, en D. M. Rivarola y G. Heisecke, Población, urbanización y recursos humanos en el Paraguay. $2^{\mathrm{a}}$ ed. Asunción, CEPES, 1970, 122. No se ha tomado en cuenta el departamento Central o Villeta, ni el distrito capital.
} 


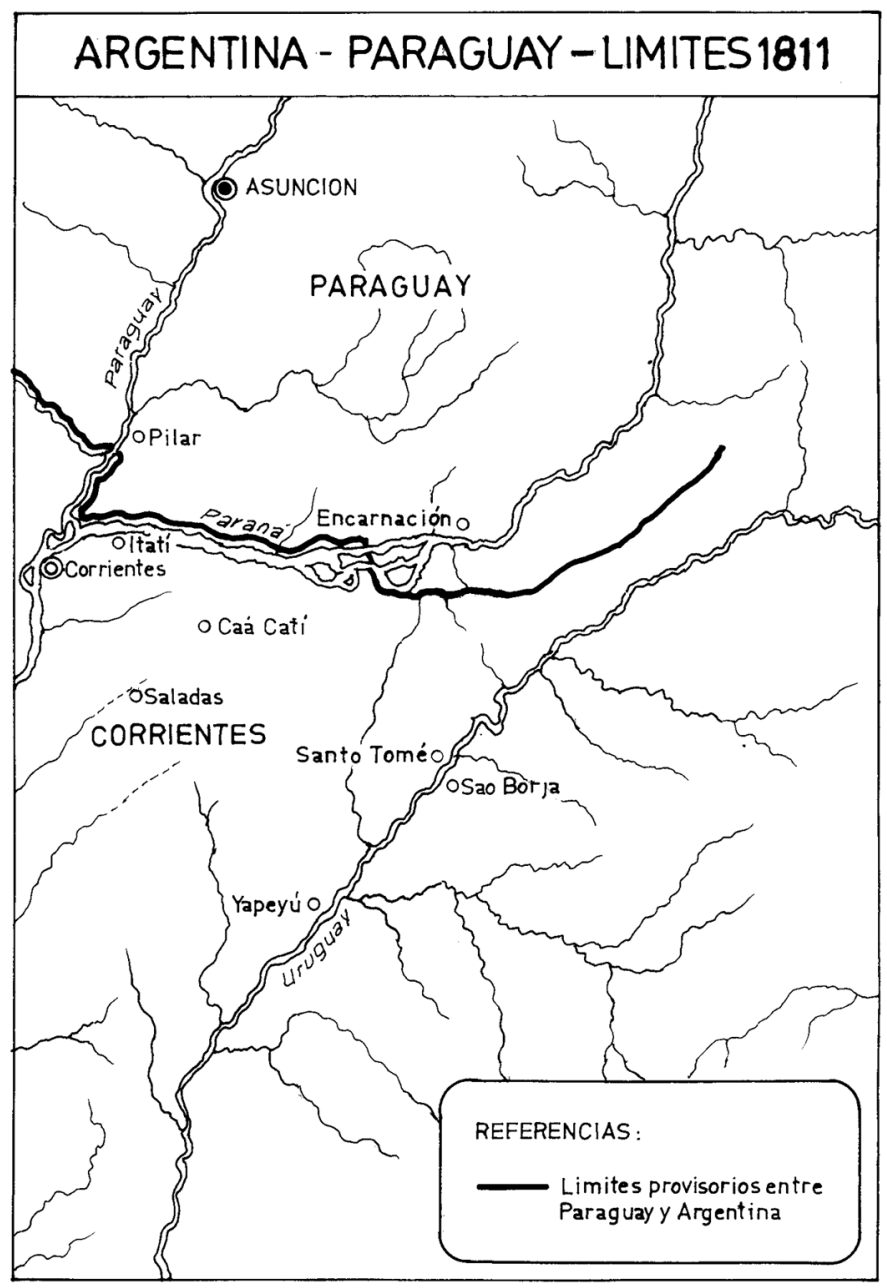

Este estado de la demarcación adquirió, en cierto momento, un nuevo status legal, a raíz de las alianzas que la provincia de Corrientes estableció con el gobierno del Paraguay del presidente Carlos A. López, y en contra de la política de Rosas. El 31.VII.1841, ambos gobiernos ratificaron un tratado de comercio y otro de límites. En este último se reconoció por parte de Corrientes la jurisdicción paraguaya sobre el campamento de San José y los pueblos del extinguido departamento de Candelaria, a la vez que se reconocía la isla de Apipé como correntina. Ello "sin perjuicio de los derechos de ambas repúblicas". La victoria federal en Arroyo Grande el 6.XII.1842, dejó sin efecto el tratado.

En ocasión de un nuevo enfrentamiento contra Rosas, la provincia volvió a buscar la alianza militar del Paraguay, y rubricó el tratado del 11.XI.1845. El mismo reprodujo los mismos artículos de 1841 referidos a los límites entre ambas jurisdicciones. La derrota de los hermanos Madariaga también dejó sin efecto esas disposiciones. Cabe recordar que desde 1842 el Paraguay había declarado formalmente su independencia y que ésta 
había sido reconocida por el Brasil en 1844, y luego por otras naciones. En cambio, la Confederación Argentina, conducida por Rosas, desconoció esa situación, temiéndose a fines de los años cuarenta, un conflicto armado ante aquella situación.

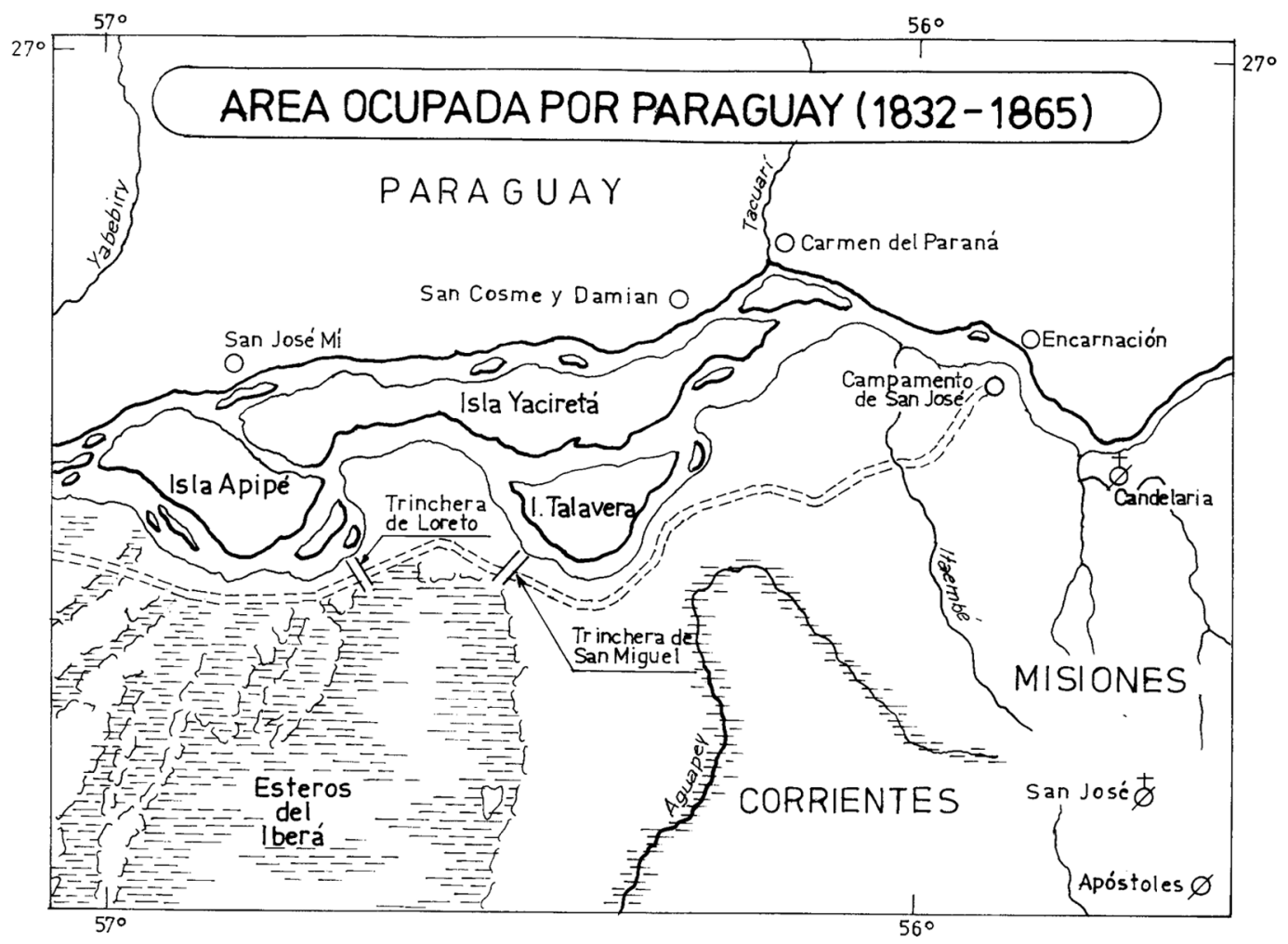

La cuestión de límites volvió a complicarse en 1849. El presidente López ratificó los derechos paraguayos sobre Candelaria y fue autorizado por un congreso a ocupar todo el territorio de Misiones, desde el Paraná al Uruguay. Dos divisiones paraguayas se hicieron presentes en ese ámbito, reforzaron sus guarniciones y tuvieron escaramuzas con milicias correntinas, aunque sin llegar a la guerra. Finalmente, y de modo sorpresivo, el presidente López intentó en XI.1849 un acercamiento con la Confederación, proponiendo, entre otras cosas, dejar el problema de límites en suspenso hasta la celebración de un congreso general con la Confederación. La oferta fue rechazada por Rosas, que ante la invasión paraguaya obtuvo de la Legislatura de Buenos Aires la autorización para proceder militarmente y reincorporar al Paraguay a la Confederación.

El pronunciamiento de Urquiza y la constitución de una alianza contra Rosas impidieron esta acción y tras la derrota de Caseros, Urquiza asumió la dirección de la Confederación. Encomendó a Santiago Derqui negociar un acuerdo con el Paraguay, del que resultó una declaración fechada el 17.VII.1852, por la cual Paraguay cedía el departamento Candelaria en Misiones, pero obtenía plena jurisdicción sobre ambas costas del río Paraguay y el límite del río Bermejo sobre el Chaco Austral de Argentina. El 
acuerdo de límites no fue aprobado por el Congreso de la Confederación, de modo que la cuestión seguirá pendiente hasta 1876. (Cháves, 1922, Quesada, 1902 y Mantilla, 1928).

La ocupación paraguaya, desde el nordeste correntino hasta Corpus en Misiones, fue efectiva y tuvo continuidad hasta 1865. Las guardias establecidas en las tranqueras de Loreto y San Miguel y en el campamento de San José, así como los movimientos de tropas, que en los años de mayor tensión llegaron hasta las costas del río Uruguay, se mantuvieron después de Caseros y permanecieron allí hasta la guerra. El repliegue paraguayo en la región recién se produjo como consecuencia de la rendición de sus fuerzas en Uruguayana y el abandono del Campamento de San José, en septiembre de 1865.

\section{Guerra con el Paraguay y demarcación definitiva de la frontera internacional}

La cuestión limítrofe quedó estancada como consecuencia de la negativa argentina a aceptar la línea del río Bermejo como límite internacional. Desde entonces y hasta el estallido de la guerra en 1865, el Paraguay procuró consolidar su dominio en el Chaco Central y Boreal. Entre otras iniciativas, fundó allí la colonia Nueva Burdeos en 1855, en el sitio de una antigua reducción indígena. Si bien esta colonia no llegó a prosperar, el lugar continuó ocupado por la primera Villa Occidental del Paraguay, que la sucedió. Esta y otros puntos al norte del río Pilcomayo se fueron ocupando, así como también se dispuso por parte del presidente López la venta de extensas áreas del Chaco Central en beneficio de Elisa Lynch.

Los conflictos que se suscitaron entre el Paraguay y el Brasil, así como el propósito del presidente López de intervenir en la lucha intestina del Uruguay, condujeron a un agravamiento de la situación bélica en el Río de la Plata. Confiado el presidente López en el apoyo argentino para operar sobre las tropas brasileñas en Río Grande y auxiliar al gobierno del Uruguay, solicitó autorización para que sus fuerzas, acantonadas en San José de la Rinconada transitaran por el territorio de Corrientes en esa dirección. Dicho permiso le fue negado, amparándose en la neutralidad argentina. Ello produjo la declaración de guerra del Paraguay el 18.III.1865 y el posterior ataque a Corrientes el 13.IV. A su vez, la Argentina se unió a Brasil y Uruguay por el Tratado de la Triple Alianza del 1.V.1865, en el cual se indicaban las aspiraciones limítrofes del Brasil y de la Argentina. Se trataba, en este último caso, de la frontera del río Paraná y en el Chaco la pretensión de soberanía desde el Bermejo hasta Bahía Negra, es decir todo el Chaco Central y Boreal.

Vencido el Paraguay, los aliados acordaron iniciar los términos de paz y de límites. Como es sabido, estas negociaciones implicaron graves desinteligencias entre los aliados, que condujeron, en enero de 1872, a la firma de la paz por separado entre el Paraguay y Brasil, con indicación de los límites entre ambos estados. La Argentina reaccionó ante esa política que contravenía el tratado de alianza y en ese año ocupó militarmente la Villa Occidental, como sede del gobierno del Territorio Nacional de Chaco creado en esa oportunidad. La diferencia en la cuestión de límites, ya no radicaba en Misiones, sobre lo que había acuerdo, sino en la pretensión argentina de tener jurisdicción sobre todo el Chaco, pretensión que era resistida por el Brasil. 
Las complejas negociaciones continuaron desde 1872 hasta fines de 1875, en medio de tensiones y desencuentros. Finalmente, el 3.II.1876 se acordó el tratado Machain Irigoyen, por el cual se estableció la paz y se acordaban los límites. En el este, el río Paraná como línea divisoria entre ambos estados, la isla de Apipé y la del Cerrito para la Argentina; Yaciretá para el Paraguay. Y en el oeste, el río Pilcomayo sería el límite internacional aceptado. A su vez, Argentina reconocía al Paraguay la jurisdicción del Chaco Boreal desde Bahía Negra al río Verde, y se dejaba para el arbitraje internacional, la porción sur, entre el río Verde y el Pilcomayo.

Expuestas las respectivas memorias ante el árbitro internacional, que fue el presidente de los Estados Unidos Rutherford Hayes, éste se pronunció el 12.XI.1878 en favor del Paraguay, el área del Chaco en discusión. La Argentina, en consecuencia, desocupó Villa Occidental el 14.VI.1879 y replegó la sede de la gobernación del Chaco a la localidad de Formosa. A partir de entonces esos fueron los límites definitivos entre ambos estados. (Rey Balmaceda, 1979, Luchetti, 1977).

\section{La reorganización posterior de la frontera}

La relación entre ambos países se normalizó, una vez que concluyó la delimitación de la frontera. La vinculación y los intercambios se incrementaron desde entonces, favorecidos por una relación ahora pacífica y estable.

Esta nueva situación dio lugar a un proceso de reorganización de ambas fronteras. El mismo se inició en la década de 1870 y se prolongó por algunas décadas, a través de políticas y modalidades propias de cada país. El Paraguay, gravemente dañado por la guerra, debió esperar la lenta recuperación de los departamentos limítrofes, ubicados sobre los ríos Paraguay y Alto Paraná. La Argentina, salvo en el tramo de la frontera que correspondía a la provincia de Corrientes, debió abocarse a la ocupación y organización de Misiones y del Chaco, cuyos espacios fronterizos se hallaban despoblados y carentes de una estructura político administrativa consolidada.

Una vez reorganizados los respectivos distritos limítrofes, se abrió una nueva etapa de creciente vinculación fronteriza. Ello es perceptible ya en las primeras décadas del siglo XX. El aumento de la población y la urbanización en esas áreas, la multiplicación de los medios de transporte y el desarrollo de las actividades económicas, afianzadas por emprendimientos binacionales, permite seguir el curso de creciente complejidad que adquiere la relación entre ambas fronteras.

\section{La estructura político administrativa en ambas fronteras}

La organización política que existía en ambas fronteras era muy dispar, como lo demuestra la lectura de los mapas de la década de 1870. En el Paraguay, la región fronteriza estaba poblada desde antiguo y se hallaba inicialmente dividida en pequeñas circunscripciones, que después de 1900 se agruparon en departamentos de mayor extensión. Sobre el río Paraguay se ubicaron los departamentos Central y Ñeembucú. Este 
último también se extendía sobre el Alto Paraná. Hacia el este y sobre este mismo curso fluvial se hallaban los departamentos de Misiones e Itapúa.
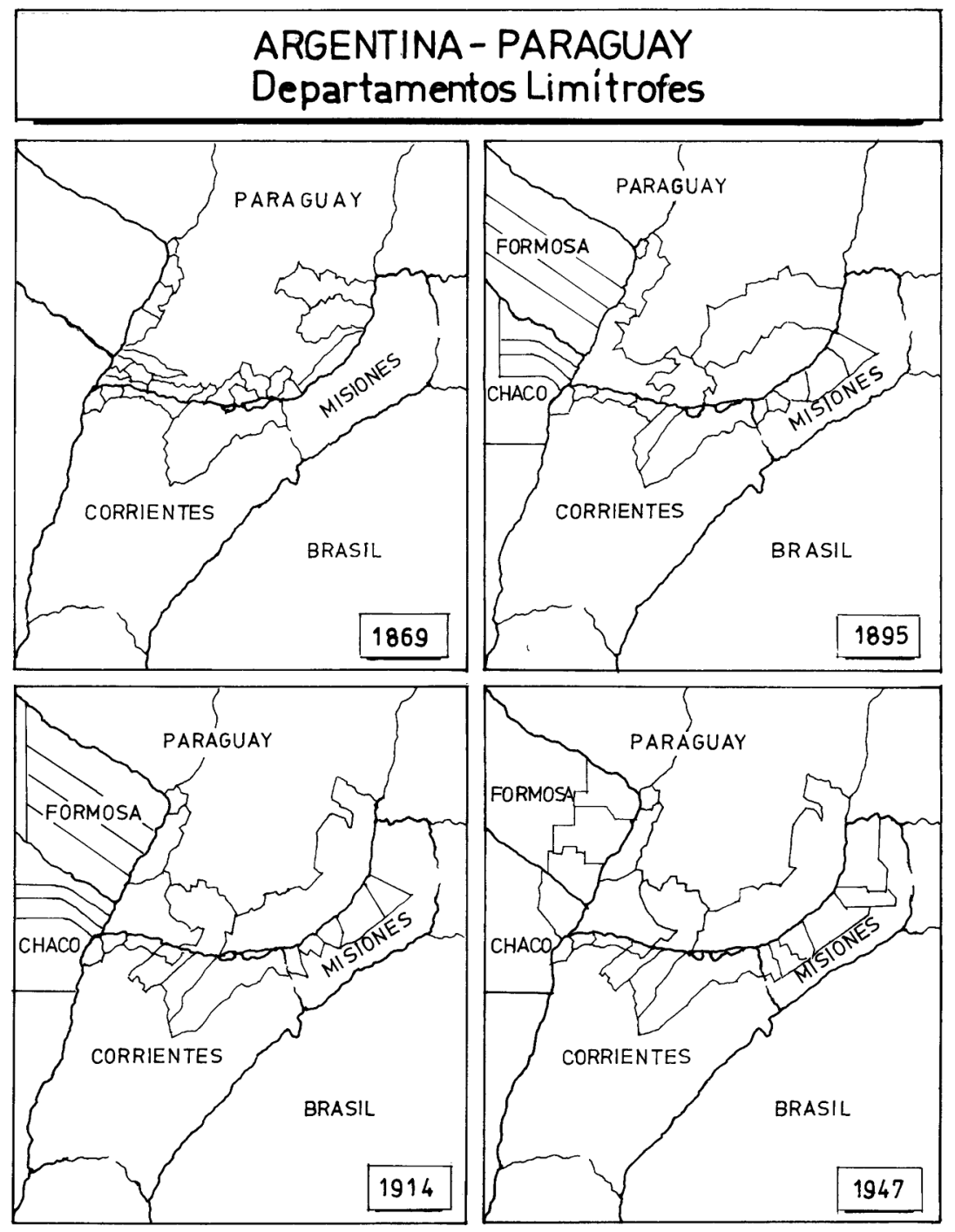

En la década de 1940, la sección norte de este último departamento se dividió y dio lugar al departamento Alto Paraná. Las cabeceras de cada uno de esos distritos fueron las localidades de Villeta, Pilar, San Juan Bautista, Encarnación y Hernandarias. Esta última fue luego reemplazada por Puerto Presidente Stroessner, hoy Ciudad del Este. En la Argentina, el único sector de la frontera que se hallaba organizado y poblado, desde antiguo, era el que correspondía a la provincia de Corrientes. Sus departamentos de San 
Cosme, Itatí, Berón de Astrada e Ituzaingó, se hallaban ubicados sobre la margen izquierda del Alto Paraná.

Hacia el este, el distrito de Misiones se hallaba entonces despoblado y carecía de organización. La provincia de Corrientes procuró incorporarlo a su jurisdicción, creando en 1870 el departamento de Candelaria. Pero en 1881 el Congreso Nacional erigió en ese distrito el Territorio Nacional de Misiones. Para su mejor administración, ese territorio fue dividido en departamentos. En 1895, los que se hallaban ubicados sobre la margen del río Alto Paraná y frente al Paraguay eran Posadas, Candelaria, San Ignacio, Campo Grande y San Pedro. En 1914 se agregó el departamento Frontera; en 1947, la nómina se había ampliado y comprendía los departamentos de Posadas, Candelaria, San Ignacio, Cainguas, San Pedro e Iguazú. La capital del Territorio se ubicó en Posadas.

Algo semejante ocurrió en el Chaco. La cuestión de límites precipitó la creación en 1872 del Territorio Nacional de Chaco. Este abarcaba inicialmente desde el norte de Santa Fe hasta Villa Occidental. Más tarde, en 1884, ese territorio se fraccionó en las gobernaciones de Formosa y del Chaco. La primera abarcaba la región del Chaco Central, entre los ríos Pilcomayo y Bermejo; la segunda, el Chaco Austral, desde el Bermejo hasta el Arroyo del Rey. El río Paraguay era el límite con los vecinos departamentos Central y Ñeembucú. Formosa constituyó la sede de sus autoridades en la colonia homónima y el Chaco la suya en Resistencia.

También estos territorios se dividieron en departamentos. En el Chaco, para 1895, se denominaron Martínez de Hoz, Solalinde, Guaycurú y Resistencia; en 1914 se les agregó el departamento La Sabana y en 1947, esa estructura departamental se redujo a dos distritos. Resistencia y Río Bermejo. Los departamentos formoseños, linderos con el Paraguay se titulaban, Formosa, Segundo, Tercero y Cuarto y así se mantuvieron en 1895 y 1914. En 1947 la nómina se redujo a tres: Pilcomayo, Formosa y Laishí. (Cacopardo, 1967).

Esa estructura político administrativa, además de contar con las autoridades respectivas, se vio apoyada en Argentina por la instalación de líneas telegráficas, receptorías de rentas y delegaciones de la prefectura naval. Esta última velaba por la seguridad y vigilancia de la intensa navegación que circulaba entonces por ambos ríos. En la década de 1880, esa policía marítima distribuyó sus subprefecturas a lo largo de los principales puertos del litoral.

\section{Las comunicaciones fluviales y ferroviarias}

En esta etapa aumentaron las comunicaciones, contribuyendo a modificar el secular aislamiento en que se hallaba la región. Desde antiguo, la única vía de comunicación era la navegación fluvial. Ocasionalmente, también se cruzaba en balsas el ganado en pie desde Corrientes y se mantenían intercambios de limitada dimensión entre los vecinos de ambas costas. La situación privilegiada de Corrientes había convertido a esta ciudad en una escala obligada para las embarcaciones que iban o llegaban desde Asunción por el río Paraguay, o por aquellas que seguían por el Alto Paraná hacia Misiones. En este último caso, los 
rápidos de Apipé constituyeron por mucho tiempo un obstáculo difícil de superar. En Ituzaingó se hacía necesario transbordar a embarcaciones de menor calado para seguir la navegación hasta Posadas o Encarnación, y también proseguir hacia los puertos naturales existentes aguas arriba, hasta alcanzar Iguazú en Misiones o Tacurú Pucú en el Paraguay. En la ribera argentina, diligencias y mensajerías también permitían a los pasajeros salvar el tramo Ituzaingó Posadas por la entonces precaria ruta terrestre. (Pérez, 1993).

El movimiento de los barcos fue considerable desde fines del siglo XIX y la primera mitad del XX. Los barcos de vela fueron paulatinamente reemplazados por lanchas, chatas, remolcadores y vapores de carga y pasajeros. La inexistencia de caminos y de ferrocarriles hacía de la navegación fluvial la vía más segura y rápida. Ello favoreció la radicación de numerosas poblaciones a lo largo de ese extenso litoral fluvial.

Sobre el río Paraguay, en la costa argentina, se habilitaron puertos en Formosa y en Barranqueras, y también en localidades de menor rango, como Pilcomayo, Las Palmas y Bermejo. Tiempo después, esos puertos contaron con depósitos y muelles, que se fueron consolidando y mejorando en las décadas de 1930-1940. Desde la costa paraguaya las localidades de Pilar y Alberdi mantuvieron un activo intercambio con sus vecinas argentinas de Bermejo y Formosa.

En el curso del Alto Paraná, los puertos principales eran Posadas y Encarnación, ciudades que, desde sus inicios, mantuvieron un activo intercambio. Entre Corrientes y Posadas no había localidades importantes. Desde Posadas aguas arriba se multiplicaban los puertos naturales, embarcaderos y planchadas, aptos para el acopio y la carga de maderas y yerba. Con la radicación de colonias y pueblos, dichos puertos fueron mejorando y ampliando sus instalaciones, así como también los servicios de las compañías de navegación que servían esas localidades.

El neto predominio de la navegación como medio de transporte y comunicación en la región se mantuvo hasta mediados de la década de 1950. Desde entonces sus servicios comenzaron a declinar ante la creciente competencia de los transportes terrestres, favorecidos por la mejora y la pavimentación de las rutas principales.

Un avance importante en las comunicaciones terrestres fue la conexión entre el FCNE (hoy FC General Urquiza) y el FC del Paraguay. Ambas líneas llegaron a Posadas desde Buenos Aires y a Encarnación desde Asunción en 1911. La habilitación de un ferry boat en 1913 permitió el cruce de los trenes y la interconexión de ambas líneas.

La red vial tuvo inicialmente una importancia secundaria. Los caminos de tierra, intransitables en épocas lluviosas, se hallaban destinados para la conducción de haciendas y vehículos de tracción a sangre. Pero la generalización del uso de los automotores en las décadas de 1930 y 1940 dio impulso a una serie de mejoras en su mantenimiento. De todos modos, la utilización generalizada de los mismos, sólo se produjo cuando las rutas comenzaron a ser pavimentadas en la década de 1960 en Argentina, y algo más tarde en el Paraguay. (Maeder y Gutiérrez, 1996, Pérez, 1985). 


\section{Evolución de la población en la frontera (1886-1950)}

Un creciente interés económico, acompañado por la radicación de pobladores en las áreas fronterizas de ambos países se hizo manifiesto ya a fines del siglo XIX, y se incrementó paulatinamente, a través de colonias agroindustriales y explotaciones forestales y yerbateras.

Los datos censales de ambos países permiten seguir, al menos aproximadamente, la evolución demográfica de esas poblaciones entre 1886 y 1950. A tal efecto se han comparado los datos de los censos nacionales argentinos y paraguayos, tomando en cuenta la población existente en los respectivos departamentos de la frontera.

Paraguay. Población de los departamentos limítrofes sobre los ríos Paraguay y Alto Paraná (1886-1970)

\begin{tabular}{|l|r|r|r|r|r|}
\hline Departamentos & \multicolumn{1}{|c|}{$\mathbf{1 8 8 6}$} & \multicolumn{1}{c|}{$\mathbf{1 8 9 9}$} & \multicolumn{1}{c|}{$\mathbf{1 9 1 4}$} & \multicolumn{1}{c|}{$\mathbf{1 9 3 6}$} & \multicolumn{1}{c|}{$\mathbf{1 9 5 0}$} \\
\hline Neembucú & 15.398 & 26.614 & 30.034 & 30.674 & 50.861 \\
Misiones & 10.455 & 21.065 & 30.092 & 53.619 & 43.449 \\
Itapúa & 18.578 & 26.987 & 38.285 & 78.109 & 111.424 \\
Alto Paraná & & & & 2.751 & 9.531 \\
\hline Totales & 44.431 & 74.666 & 98.911 & 171.153 & 215.265 \\
\hline
\end{tabular}

Argentina. Población de los departamentos limítrofes sobre los ríos Paraguay y Alto Paraná (1869-1970)

\begin{tabular}{|l|r|r|r|r|}
\hline \multicolumn{1}{|c|}{ Provincias } & \multicolumn{1}{c|}{$\mathbf{1 8 6 9}$} & \multicolumn{1}{c|}{$\mathbf{1 8 9 5}$} & \multicolumn{1}{c|}{$\mathbf{1 9 1 4}$} & \multicolumn{1}{c|}{$\mathbf{1 9 4 7}$} \\
\hline Corrientes & 9.175 & 16.694 & 27.051 & 38.422 \\
Misiones & & 12.034 & 24.575 & 146.615 \\
Chaco & & 8.894 & 43.938 & 132.561 \\
Formosa & & 5.110 & 14.247 & 57.195 \\
Totales & & 42.732 & 109.811 & 374.793 \\
\hline
\end{tabular}

La distribución de la población en cada uno de los tramos de esta extensa frontera era muy desigual en el último cuarto del siglo XIX. La ocupación de aquellos espacios, entonces virtualmente vacíos, modificó pronto aquel desequilibrio inicial.

Ello es claramente perceptible en el río Paraguay, luego que la Argentina creó allí los Territorios Nacionales del Chaco y Formosa. La explotación forestal aplicada a 
la producción de tanino, la instalación de complejos agroindustriales como Las Palmas (1888), así como la conexión de las terminales ferroviarias con los puertos de Barranqueras y Formosa (1909-1911) contribuyeron al rápido poblamiento de aquella franja litoral. Los departamentos paraguayos ubicados en la margen opuesta del río, si bien se hallaban poblados desde el siglo XVIII, no recibieron idéntico impulso en esta etapa. Predominó en ellos la ganadería, que diezmada por la guerra, comenzó a reponer sus rodeos a través de la importación de ganado en pie desde Corrientes. (Kleipenning, 1992 y Bünstorf, 1982).

Los departamentos de la provincia de Corrientes y del Paraguay sobre el río Alto Paraná, mantuvieron su antigua vinculación. El desarrollo demográfico en unos y otros fue limitado, sin que se produjeran cambios estructurales de fondo en ambos casos. Sólo el pueblo de Ituzaingó, de lánguida existencia, alcanzó un notable relieve, cuando en la segunda mitad de la década de 1970 se iniciaron allí las obras de la represa binacional de Yaciretá.

En cambio, el tramo nordeste de la frontera, entre Posadas y Puerto Iguazú o entre Encarnación y Hernandarias, muestra un cambio significativo. Inicialmente, ambos espacios se hallaban escasamente poblados y carentes de organización y servicios. Pero en esta etapa se vieron favorecidas por el interés que suscitaron en una y otra frontera las actividades extractivas de la yerba mate y las maderas, así como también la radicación de colonias agrícolas y la incorporación de inmigrantes. Ello dio lugar a que el departamento Itapúa sextuplicara su población en 65 años y que los departamentos en el Territorio de Misiones aumentaran doce veces su población en 52 años. (Kleipenning, 1992, Bruniard, 1993, Schuster, 1929, Bernalt y Pedroso, 1977).

Varias colonias se asentaron en ese departamento paraguayo, como Hohenau, Obligado, Bella Vista y Capitán Meza. En la margen izquierda del Alto Paraná y en territorio argentino, se fundaron las colonias de Puerto Rico, Montecarlo y Eldorado, entre otras. En el tramo superior del mismo río, otras localidades como Wanda, Puerto Esperanza o Puerto Iguazú, constituyeron asentamientos con finalidades agro industriales o de turismo, cuyo posterior desarrollo se consolidó en las últimas décadas del siglo. (De Marco, 1980, Bartolomé, 1982, Borrini, 1980).

\section{Argentina y Paraguay}

Poblaciones urbanas en ambas fronteras (1947-1950)

\begin{tabular}{|l|r|r|l|r|r|}
\hline Centros urbanos & $\mathbf{1 9 4 7}$ & $\mathbf{1 9 5 0}$ & Centros urbanos & $\mathbf{1 9 4 7}$ & $\mathbf{1 9 5 0}$ \\
\hline Posadas & 37.588 & & Clorinda & 5.910 & \\
Formosa & 16.506 & & Las Palmas & 4.358 & \\
Encarnación & & 13.321 & Puerto Bermejo & 3.063 & \\
Barranqueras & \multirow{2}{*}{12.315} & & Ituzaingó & 2.230 & \\
Pilar & & 5.001 & Hernandarias & & 660 \\
Alberdi & & 1.310 & Carmen del Paraná & & 2.310 \\
\hline
\end{tabular}


Si bien la población era mayoritariamente rural, es perceptible un lento proceso de urbanización. Hacia mediados del siglo, las poblaciones de mayor dimensión eran las capitales de los Territorios Nacionales en la Argentina y las sedes administrativas de los departamentos de Itapúa y Ñeembucú en el Paraguay. En el resto de las poblaciones ribereñas, la dimensión urbana aún era incipiente.

Los restantes pueblos y puertos sólo tenían poblaciones inferiores a 2.000 habitantes, no registradas en el censo argentino de 1947. (Maeder y Gutiérrez, 2003).

\section{Epílogo}

A mediados del siglo XX, el proceso de apertura y vinculación en la frontera argentino paraguaya, parecía hallarse encaminado. Quedaban atrás el antiguo aislamiento, la indefinición de los límites nacionales y la marginalidad de vastos espacios, secularmente despoblados. En las últimas décadas, ese proceso de apertura, lejos de detenerse, se amplió y se tornó cada vez más complejo, sobre todo en su dimensión social.

\section{Referencias Bibliográficas}

Alvear, Diego de. 2000 (1836). Relación histórica y geográfica de la provincia de Misiones. Documentos de Geohistoria Regional No12. Instituto de Investigaciones Geohistóricas Conicet, Resistencia, ChacAudibert, Alejandro. 1892. Los límites de la antigua provincia del Paraguay, Buenos Aires, ed. La Economía de Iustoni Hermanos y Cía.

Bartolomé, Leopoldo. 1982. Colonias y colonizadores. Posadas, Universidad Nacional de Misiones. Bernalt, Mario y Celso Pedroso. 1977. "Modalidades de ocupación del espacio en el este paraguayo". En: Revista de Estudios Regionales $\mathrm{N}^{0} 2$.Centro de Estudios Regionales del Nordeste Argentino, Corrientes, pp.63-82.

Borrini, Héctor.1980. "La población de Misiones y su evolución en el área de frontera". En: Folia Histórica del Nordeste, $\mathrm{N}^{\mathrm{o}} 4$.Resistencia, Instituto de Investigaciones Geohistóricas, Conicet e Instituto de Historia, UNNE, pp.91-118.

Bruniard, Enrique D. 1993. Paraguay. Ensayo de interpretación geográfica. Cuadernos de Geohistoria Regional No 27, Resistencia, Instituto de Investigaciones Geohistóricas, Conicet.

Bünstorf, Jürgen.1982. "El papel de la industria taninera y de la economía agropecuaria en la ocupación del espacio chaqueño". En: Folia Histórica del Nordeste. № 5, Resistencia pp.760.

Cacopardo, María Cristina. 1967. República Argentina. Cambios en los límites nacionales, provinciales y departamentales a través de los censos nacionales de población. Buenos Aires, Instituto Di Tella.

Carbia, Rómulo D.1914. Historia eclesiástica del Río de la Plata, Tomo 1, Buenos Aires, Alfa y Omega.

Chaves, Julio César. 1955. El presidente López. Vida y gobierno de Don Carlos. Buenos Aires, Ayacucho.

De Marco, Graciela. 1980. "Misiones: su poblamiento entre 1895 y 1970". En: Primer Encuentro de Geohistoria Regional, Corrientes, Instituto de Investigaciones Geohistórica, Conicet.

Kleipenning, Jan.1992. Rural Paraguay. 1870-1932. Amsterdam, CEDLA (Latin American 
Studies 66)

Lorenzo, Héctor y Esteban A. Snihur. 1991 “La Trinchera de San José”. En: Estudios Regionales $\mathrm{N}^{\circ} 1$, Posadas, FHyCS de la UNaM, pp.66-72.

Luchetti, Aurelio A. 1977. "Límites fronterizos: estado actual de su demarcación". En: Estrategia $\mathrm{N}^{0}$ 46-47. Instituto Argentino de Estudios Estratégicos y de las Relaciones Internacionales, Buenos Aires, pp 93-102

Maeder, Ernesto J.A.1979. "Antiguas poblaciones en la costa de Formosa y el origen del topónimo" En: Investigaciones y Ensayos No26. Buenos Aires, Academia Nacional de la Historia, pp. 439-452.

Maeder, Ernesto J.A. y Ramón Gutiérrez. 1996. Atlas histórico del Nordeste Argentino. Resistencia, Instituto de Investigaciones Geohistóricas, Conicet.

Maeder, Ernesto J.A. y Ramón Gutiérrez. 2003. Atlas del desarrollo urbano del Nordeste Argentino. Resistencia, Instituto de Investigaciones Geohistóricas, Conicet.

Maeder, Ernesto J. A. 1981. Historia de Corrientes en el período virreinal (1776-1810). Buenos Aires, Academia Nacional de la Historia.

Maeder, Ernesto J. A. 1992. Misiones del Paraguay. Conflicto y disolución de la sociedad guaraní. Madrid, Mapfre.

Mantilla, Manuel F.1929. Crónica Histórica de Corrientes, Buenos Aires. Espiasse y cía.

Mendoza, Raúl.1970. "Desarrollo y evolución de la población paraguaya". En: D. M. Rivarola y G. Heisecke, Población, urbanización y recursos humanos en el Paraguay. $2^{\circ}$ ed. Asunción, CEPES.

Pastells, Pablo. 1930. Historia de la Compañia de Jesús en la Provincia del Paraguay. (Argentina, Paraguay, Uruguay, Perú, Bolivia y Brasil según los documentos originales del Archivo General de Indias, Madrid. Librería General de Victoriano Suárez.

Pérez, María Emilia.1985. "El desarrollo de las redes vial y ferroviaria en el NEA, 1872-1980". En: Historia de los correntinos $\mathrm{N}^{\mathrm{o}} 5$. Corrientes.

Pérez, María Emilia.1993. La navegación fluvial y el sistema portuario en el Chaco y Formosa, entre 1880 y 1960. Cuadernos de Geohistoria Regional $\mathrm{N}^{\circ} 28$, Resistencia, Instituto de Investigaciones Geohistóricas, Conicet.

Poenitz, Edgar y Alfredo Poenitz. 1993. Misiones, provincia guaranítica. Defensa y disolución (1768-1830). Posadas, UNAM.

Quesada, Ernesto. 1902. La politica argentino paraguaya. Buenos Aires, Bredhal

Rey Balmaceda, Raúl.1979 Límites y fronteras de la Argentina. Epítome geográfico. Buenos Aires, OIKOS.

Sánchez Quell, Hipólito. 1964. La diplomacia paraguaya desde Mayo hasta Cerro Corá, $4^{\circ}$ ed. Buenos Aires, Kraft.

Schuster, Adolf N. 1929. Paraguay land, volk, geschichte wirtschaftsleben und kolonisation. Stuttgart, Strecker und Schroder.

Trelles, Manuel Ricardo. 1867. Cuestión de límites entre la República Argentina y el Paraguay. Buenos Aires, Imprenta del Porvenir.

Williams, John Hoyt. 1973. "La guerra no declarada entre el Paraguay y Corrientes". En: Estudios Paraguayos N ${ }^{0}$ 1, Asunción, Universidad Católica Nuestra Señora de la Asunción, pp.35-43. 